\title{
THE BRITISH EMPIRE AND THE ECONOMIC DEVELOPMENT OF INDIA (1858-1947)*
}

TIRTHANKAR ROY

London School of Economics and Political Science ${ }^{\mathrm{a}}$

\begin{abstract}
Interpretations of the role of the state in economic change in colonial (1858-1947) and post-colonial India (1947-) tend to presume that the colonial was an exploitative and the post-colonial a developmental state. This article shows that the opposition does not work well as a framework for economic history. The differences between the two states lay elsewhere than in the drive to exploit Indian resources by a foreign power. The difference was that British colonial policy was framed with reference to global market integration, whereas post-colonial policy was framed with reference to nationalism. The article applies this lesson to reread the economic effects of the two types of state, and reflects on ongoing debates in the global history of European expansion.
\end{abstract}

Keywords: colonialism, nationalism, developmental state, industrialisation, institutions

JEL Code: F54, N15, O10

* Received 30 May 2015. Accepted 5 October 2015. The author wishes to thank two referees and the editors of the Revista for comments and suggestions that led to significant improvements on the version submitted. An earlier draft of the paper was presented in a workshop on Colonial Legacies: Persistence and Long-run Impact on Economic Growth, January 2015, held at the Fundación Ramón Areces, Madrid. The author is grateful to the participants and organisers of the workshop for a stimulating discussion and especially to Rafael Dobado González for his constructive comments and criticisms of the paper.

a Department of Economic History, London School of Economics and Political Science, Houghton Street, London WC2A 2AE, UK. t.roy@lse.ac.uk 


\section{RESUMEN}

Las interpretaciones del papel del estado en los cambios económicos de la India colonial (1858-1947) y poscolonial (1947-) tienden a suponer que la India colonial fue un estado explotador y la India postcolonial un estado desarrollista. Este artículo muestra que esta oposición no funciona bien dentro del marco de la historia económica. Las diferencias entre los dos estados se centran en factores distintos al deseo de una potencia extranjera por explotar los recursos de la India. La diferencia reside en que la política colonial británica se construyó en referencia a la integración en el mercado mundial, mientras que la política poscolonial se estructura en torno al nacionalismo. El texto aplica este enfoque a la relectura de los efectos económicos de los dos tipos de estado, y reflexiona sobre los debates en curso acerca de la historia global de la expansión europea.

Palabras clave: colonialismo, nacionalismo, Estado del Desarrollo, industrialización, instituciones

\section{INTRODUCTION}

The literature exploring the link between European imperialism and economic development in the non-European regions has grown in the last 15 years, thanks to a shift of focus from empires as a political system towards the broader issue of European expansion and settlement. India, possibly the largest colony in territorial size and population in the $19^{\text {th }}$ century, is yet to be closely integrated within this literature. Leaving India to the margins amounts to missing an opportunity, to refine the new paradigms being used to study the economic history of European expansion. On the other hand, within India, popular and academic discourse on the economic effects of British rule is yet to absorb the new trends in global economic history, with the result that impressions of the empire still derive from ideas popularised by Marxist and nationalist historiographies of an earlier era. These theories need revision too.

The present paper is an attempt to meet this twofold gap. It revisits the subject of governance in British India, and using that discussion, offers a critique of two ways of conceptualising the economic effects of the British Empire in India. In one of these two models, the Marxist-nationalist one, the colonist country represents a dominant «core» and the colonised regions the dependent "periphery», and the core was a predatory force that ruled in order to extract surplus value from the periphery. A second approach has emerged more recently from what is known as the settler economy literature, which accords crucial political agency to the European settlers in the periphery, rather than to the core region. One strand in the discourse assumes that 
regions where the Europeans ruled but did not settle in large numbers (India was an example) were more likely to suffer predatory institutions. The present paper rejects both these approaches on one common ground, they fail to show with convincing evidence how predation was institutionalised in British India.

The paper argues that a core-periphery approach does work for India, but only when shorn of the rhetoric of surplus extraction. The relationship between the core (Britain) and the periphery (India) was driven by an overriding aim to maintain free markets in commodities and factors of production. British economic interest was an important force behind this project, but the goal was shared by many Indian capitalists as well, at least until the world economy fell in a crisis in the interwar years. The successes and the failures of the state stemmed from the manner in which this aim was pursued, rather than from the quality of institutions it created.

The rest of the paper consists of six sections. The next section discusses the comparative economic history of European expansion, and how useful the literature is for the study of Indian economic history. The section that follows describes the theory and practice of governance prevailing in British India. The subsequent sections deal with the pattern of economic change in colonial India; interpretations of how the state shaped these patterns; an account of why nationalism won the battle for economic ideology; and the regulatory order that was erected after the Empire ended.

\section{THE RAJ IN A GLOBAL ECONOMIC HISTORY CONTEXT}

«Great Britain acted as the major collector of the surplus extracted from the underdeveloped countries of today ... violence and racial discrimination were used blatantly in order to increase the size of the surplus», wrote a leading Marxist economist with specific reference to the economic experience of colonial India (Bagchi 1972). In 1972, when these words were written, conceptualising the British Empire in India (the Raj, for short) as a grand machine of surplus extraction and transfer was quite common. The concept came not so much from historical scholarship, rather it came from a worldwide critique of capitalism as an obstacle to development in the third world. The critique developed in part to revise the classical Marxist analysis of capitalism in a closed economy setting, and in part to challenge a positive assessment of global capitalism within Marxist theory ${ }^{1}$. These debates need not concern us here.

In India, the theory of predatory colonialism originated in the nationalist struggles against British rule in the early $20^{\text {th }}$ century. In turn, the nationalist paradigm arose to rebut a $19^{\text {th }}$ century liberal reading of the Raj as a force for economic modernisation, achieved by means of free markets and integration

${ }^{1}$ For example, Bill Warren's posthumously published work, which followed Karl Marx's own positive assessment of colonialism rather than the negative assessment being advanced by other Marxists (see Brewer (1990) for further discussion). 
of India in a Britain-dominated world economy. One of the pillars of Indian nationalism was the belief that the British, by forcing free trade and an open factor markets upon India, had ruined its economy and created poverty and underdevelopment. The nationalists did not employ the Marxist language of surplus extraction, but came close to it, by suggesting that Indians paid a heavy price for services purchased from Britain, which payments became known as «drain».

Between 1957 and 1975, a group of Marxists who may be loosely called the Monthly Review Press collective and included, among others, Paul Baran, Samir Amin and André Gunder Frank, discovered the Indian nationalist texts. The general idea they advocated was that the rich world, which had more capital, grew rich by transferring surplus value from the poorer world where most people worked as labourers and produced raw material. There now developed a bond between Indian nationalism and global Marxism. Both schools rejected the open economy. Whereas the former supplied a specific example of colonial exploitation, the latter erected a model of world inequality using it. The shared ground was that both believed that $19^{\text {th }}$ century colonialism was a predatory force. The imperialist liberal ideology favouring free trade and an open economy concealed the real purpose of imperialism, which was surplus appropriation on a world scale. In the 1960s and the 1970s, popular support for the "developmental state», one that made use of tariff protection, subsidies and controls to promote industrialisation, became a compatible part of the Marxist-nationalist historiography of the Empire ${ }^{2}$. The opposition between a colonial state that was predatory and a post-colonial state that was developmental made for an easy narrative of modernisation.

The proposition that the Empire was at bottom a mechanism of surplus appropriation and transfer has not fared well in global history. The pessimist brand of Marxism has not been altogether successful in refuting the classical Marxist notion that global capitalism was a source of innovation and productivity gains that were widely shared between colonist and colonised regions. It is unhelpful as a framework to explain differences between types of colonial experiences, such as that between European expansion in the New World and colonies in Asia and Africa. Colonial exploitation as a theory of world poverty makes comparative history between, say, India and China difficult. Both regions experienced broadly similar patterns of GDP growth in the $19^{\text {th }}$ century, and yet only one of the two was colonised.

Conceptually, in order to believe that colonialism is everywhere a surplus appropriation system, it is necessary to assume that lack of political freedom means lack of economic freedom for the indigenous population. Was there such a link? Did European rule necessarily compromise the economic freedom of indigenous capital and labour? India was a major source of free wage labour in the $19^{\text {th }}$ century world. Business history supplies plenty of

\footnotetext{
${ }^{2}$ On the concept of the developmental state, see essays in Woo-Cummings (ed.) (1999).
} 
examples showing that colonialism did not curb the capability of indigenous capitalists, in fact, the contrary. India's biggest conglomerate today, Tata, rose by making use of opportunities created by the world economy sponsored by the Empire. One of the world's largest cotton textile mill industries emerged in India in the $19^{\text {th }}$ century, in direct competition with Manchester. If the Raj had either the intention or the authority to stop the process it would be hard to explain how Bombay's merchants could invest in a field where Indians competed — successfully — with the most politically powerful of British industries.

Marxist historiography saw the world as divided into a dominant core and a dependent periphery. More recently, the core-periphery approach has been abandoned in a number of cases, in favour of one that accords political agency to European settlers in the peripheral regions ${ }^{3}$. The settler economy approach offers a useful alternative to the Marxist core-periphery one, in two ways. First, it renders the search for a universal theory of imperialism unnecessary. Whether or not the Spanish or the British Empire can be defined as a type of state remains a difficult question to answer. This is so because European expansion and resettlement could lead to a variety of political effects, which it would be misleading to lump under one label, «Empire» ${ }^{4}$. For the British Empire in India, which fundamentally changed in character from its early foundation by East India Company adventurers to being a Crown colony, in the process undergoing deep changes in the composition of the ruling class, it is hard to pin down the colonisation project to one single motivation or even an identifiable group of decision makers. The settler economy approach does not require an abstract theory of colonialism. Attention falls instead upon institutions of governance in each particular instance when Europeans formed a new society or polity outside Europe. The recent scholarship makes the political effect more contingent upon settlement, and thus makes politics endogenous to the regions that received European settlers. Politics involving Europeans and the native population was a bottom-up process rather than one controlled and shaped by the core. This shift allows for a more nuanced comparative history of European expansion than in the core-periphery model. Second, the settler economy literature emphasises the institutions through which power was exercised, rather than power itself. Colonialism was a bundle of institutions, and this bundle was variable. In assessing the economic legacies of colonialism, we should ask what the distinctive institutions of governance were in particular instances.

How was power institutionalised in the colonial setting? The "standard settler model», which is expected to correspond to the historical experiences

${ }^{3}$ The scholarship makes particular use of the Americas, see especially Engerman and Sokoloff (2013) and Irigoin and Grafe (2012). See Lloyd, Metzer and Sutch (eds) (2013) for a selection of recent articles and further references.

${ }^{4}$ See Darwin (2013) on the variety of political formations that was consistent with the use of the label British Empire. 
of South and Central America, North America, South Africa, Australia and New Zealand, answers this question in quite precise terms. European settlers appropriated land from the indigenous population by means of special laws, and settler states introduced formal mechanisms to reduce many types of labour to servitude ${ }^{5}$. These measures were modified over time, and given up in favour of freer market in land or labour protected by growth-promoting property and commercial laws borrowed from Europe, but not before producing long-term effects on wealth inequality, human capital formation and participatory politics. These two stylised facts have led to two general theories of colonialism and development. One of the two theories, sometimes called the "crop theory», emphasises the potential value of land for cash crop production, provided scarce labour could be harnessed for the purpose (Engerman and Sokoloff 2013). The second explanatory model, the "germ theory», emphasises the life expectancy of the Europeans in harsh tropical environments and suggests that «extractive» institutions including land grab and coercive labour regimes were more likely to persist in regions where Europeans did not settle in large numbers because of uncongenial geographical conditions (Acemoglu et al. 2001).

Despite the advantages of the settler economy approach - contextual analysis, and focus upon institutions - the approach has limitations. The regions where the Europeans formed "colonies» and the regions where European soldiers and merchants took over pre-existing empires were bound to be fundamentally different in the composition of the institutional bundle, because of the much larger weight of indigenous institutions that carried over into the colonial administrative practices in the latter case, and because maritime merchants of the Indian Ocean and planters in the Caribbean were different people who did not share similar objectives ${ }^{6}$. Economists risk losing sight of this difference when trying to generalise the settler economy approach to the whole world. If the bottom-up theory of the political process works for the New World, it does not work well for India or Indonesia, where Europeans did not settle in large numbers, predatory institutions of the same type as in the New World were missing and yet the colonist country moulded economic policy deeply.

Specifically in India, neither the crop theory nor the germ theory of colonial development works well. The stylised facts - land grab and labour servitude - were largely absent. In land rights, legislation did not discriminate between people by the ethnicity of the right holder. If anything, expatriate land-holding rights were weak compared with indigenous rights until well into the $19^{\text {th }}$ century. Europeans could not own or purchase farm

${ }^{5}$ It is necessary to add that state-mediated land distribution took a variety of forms in settler societies, often mixing coercion and market incentives. A good introduction to the literature is Lloyd, Metzer, and Sutch (eds) (2013).

${ }^{6}$ It is useful to remember the technical difference between colonialism, an ideology of rule that formed of an actual colonisation process, and imperialism, an ideology of rule that formed of empires with or without colonisation. 
lands, for example, until late 1830s, 80 years after colonisation had begun. Agricultural land was owned by peasants and landlords, and the British legislated on these rights so heavily that any land transfer, because it involved a complicated legal process, became progressively rare. Only in the case of tea and coffee cultivation were forest lands leased out by the government to plantation companies, but these actions were neither explicitly favouring the European nor did they involve transfer of property rights held by Indians before. In the case of labour servitude, the British imperial rule consistently legislated in favour of contractual rather than servile labour, though in practice the distinction could be hard to maintain especially when contracts were protected by means of penal law ${ }^{7}$. Indigenous labour practices in India had institutionalised servitude by means of the caste system. The slow but steady rise of contractual labour weakened traditional servitude. In the $19^{\text {th }}$ century, India supplied the largest numbers of migrant workers to plantation societies in the New World, such order of migration could not but destabilise the traditional servile labour relations from which some of the millions of migrants had emerged.

In short, colonial power in India was not institutionalised in the form of land grab and servile labour. India then represents a case where Europeans did not settle in large numbers and yet they did not create the institutions of extraction either. Neither the crop theory nor the germ theory offers a way to conceptualise that particular case. India is not an exception in that respect. Economic historians acknowledge that in a wide range of instances, colonial power did not conform to the "standard» settler model. Africa, for example, presents a diverse pattern of change following European expansion, though land distribution policies often resembled counterpart institutions in the New World ${ }^{8}$. Comparatively, other large examples like India and Indonesia receive less attention in the settler economy discourse ${ }^{9}$. Both examples require of us a historiography that needs to take leave of the settler economy, and go back to a top-down or core-periphery type of imperial relationship.

Empires in India and Indonesia shared a similarity, in that both originated in international trade. Economic policies in both retained an accent on trade. There were differences, of course. Dutch colonial policy in Indonesia, as exemplified by the Cultivation System, was predicated on a state that found it hard to pay for itself with local fiscal resources ${ }^{10}$. British India did not have that problem. Having inherited moderately well-off agrarian states, the Raj found itself in command of sufficient resources to

\footnotetext{
7 See Roy and Swamy (2016) for discussion on the evolution of colonial law on landed property and labour.

8 The literature on Africa is large, see Lützelschwab (2013) for a useful survey.

9 For example, Engerman and Sokoloff (2013) on both countries is noticeably tentative.

10 How far the Cultivation System was extractive and coercive in nature remains a controversial issue. For one contribution to the debate, see Elson (1994).
} 
pay for its own army, even though there was little left over for doing anything else. In its property laws, the Raj consistently maintained an attitude of regard towards the peasant. Despite the difference, in both regions economic policy was formed of metropolitan decision making (rather than settler agency) and commercial orientation (rather than natural resource

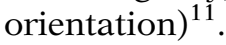

The fact that the notion of the extractive state does not have a clear meaning in the case of British India does not mean that political unfreedom did not have economic effects in this case. It only means that colonial power was institutionalised differently, and in a way that cannot be understood using the tools available from the settler economy literature. Political power was institutionalised in British India at quite a different level of economic organisation from the kind of microeconomic regulations that settler societies saw develop. It was institutionalised in macroeconomic management, in fiscal and monetary policy in operation in British India.

It is necessary, then, to consider in more detail how this regime was designed, and what it aimed to achieve.

\section{THE THEORY AND PRACTICE OF ECONOMIC GOVERNANCE}

One of the first things we need to notice about the imperial state in India is that it was a small government, not only in comparison with Britain but also other emerging economies of the time such as Imperial Russia and Meiji Japan. Tax revenue formed about 3 per cent of GDP and public administration 5 per cent in 1931. The proportions were considerably higher in these other cases. Tax per head in India was smaller than even many of Britain's tropical colonies (see below). A second notable feature of the state was that the Indian market was one of the least regulated and protected. It is tempting to conclude that this state was an experiment in classical political economy, which advocated a small government and free markets. The libertarian message was indeed applied to India by the early $19^{\text {th }}$ century ideologues and even some rulers (see Barber 1975, especially on J.R. McCulloch).

And yet, the link between economic theory and colonial policy was not as straightforward as we may think. Classical liberalism, with its belief in liberty, came to accept the idea of colonies and unfreedom not without tortuous reasoning (Winch 1965). The joining of free trade with the Empire by Parliamentary lobbies was not always inspired by economic theory (Semmel 1970). Scholars who have studied how colonial policies were implemented find that the link between doctrine and practice varied over time and between contexts of practice. For the rulers of India, economics

11 The influence of merchants and bankers behind British imperial policy has been explored in a well-known scholarship, see Cain (2012) for a survey. Many of them had multinational interests, and in that respect differed from businesses rooted in Britain. 
was sometimes useful merely as an excuse for policy (Ambirajan 1978). Therefore, whether classical economics supplied a firm justification for small government and free markets or merely rationalised a situation that was more or less forced upon the Raj remains an open question (Berg 1979). Further complicating matters, the force of ideas changed because free trade and small government invariably generated backlash. Free trade, in one view, was no more than an excuse for pushing British goods in the colonies. It is also said that it was not liberalism at all, but another $19^{\text {th }}$ century intellectual movement, utilitarianism, with a belief in the rule of law that shaped statecraft in India (Stokes 1959).

Reading the British Indian state with the lens of a $19^{\text {th }}$ century political ideal faces a further problem. Many pre-British Empires in India also shared the two features, small government and unregulated markets. Recent interpretations of the Mughal state and fiscal system have revised earlier views of a highly centralised state, by placing a great deal of stress on the dependence of the political centre upon local power structures, consisting of the landlords and military tenure holders known as jagirdars and zamindars, among others (Hasan 2004). Beyond collecting taxes, the state did not have a policy on regulating markets either. Merely having the outward features of a liberal ideal — small state and free trade — did not make the Raj distinctive.

What did make the Raj special were two other features. First, it was a military-fiscal state. Unlike any other South Asian state of the past, the Raj centralised the military and fiscal operations, in the process suppressing and demilitarising the armed groups like jagirdars and zamindars who earlier collected taxes and enjoyed local political power. Such people, if they rebelled together, could bring an Empire down. In order to suppress them and secure its own future, the British raised a large standing army, funded it by a bureaucratic fiscal machine, and through that army, imposed political unity on a region where power had always been fragmented and localised. Property right reforms that transformed the claim of the magnates upon land from fiscal to ownership rights, and saw the state appropriate the fiscal operation, also aided the process. The origin of such a state in India needs to be explained with reference to the conflicts and contests of the $18^{\text {th }}$ century, through which the East India Company established power. The Company's strategy to concentrate military and fiscal power at the centre made it a distinctively new kind of rule in India, and an essentially European one, in comparison with most of its Indian contenders. A new scholarship shows why the Company succeeded as a military-fiscal state, whereas its Indian rivals often failed, and emphasises the European dimension in Company's strategy and statecraft in late $18^{\text {th }}$ century India ${ }^{12}$.

Second, whereas most Empires of the past had a tenuous access to the seaboard, the Raj controlled the seaboard firmly, and used that control to

12 Two examples are Roy (2013) and Oak and Swamy (2012). 
foster maritime trade. The Raj emerged, not from outright conquest, but from the activities of the East India Company between 1765 and 1818. The Company was a merchant firm. Although it had left its commercial legacy far behind in 1858 when it was removed from the formal rule of India, it understood the commercial importance of India, especially its port cities. The Crown carried on the commitment to protect overseas trade, increasingly driven by a belief that India and the Indian Ocean were crucial to securing Britain's own future.

Many pre-British regimes in India may have entertained ambitions of fostering market integration on a large scale. However, they did not have the means to do so. The Raj had the means, a large military force to begin with, and used these to foster economic globalisation. Such a state cannot be understood either as a limited government or as a free trader. It was a government small in size but strong in military might, and it used power to keep trade routes open, extend the network of routes and thus sustain and extend market integration on a world scale. Again, we would go too far to suggest that the Empire did this to serve one overriding aim, be it ideology, British business interest, or political interest, or indeed the lure of resources. It would be safer to say that the Raj functioned as if it saw itself as the guardian of a set of interconnected markets. While liberalism does not fully explain why the Raj did what it did, its actions did follow a liberal blueprint. Instead of looking at the Empire as one kind of state, we can therefore perceive the Empire as the guardian of a network of markets, or what one historian describes as «an enabling system for global capitalist operations» (Osterhammell 2014, p. 454) ${ }^{13}$.

In the $19^{\text {th }}$ century, the global capitalism was made up of unprecedentedly larger flows of goods, capital and labour, thanks to the Industrial Revolution and new communication technologies, together with a compatible political and institutional setup supplied by the Empire, which encouraged British investment abroad. The Empire fostered a common language of business, uniform laws and easy exchange of knowledge over a large part of the globe (Roy 2012). Together, rising market exchange resulting from fall in trade costs and the emergence of a pro-market political force spawned a network of multinational businesses.

With what instruments did the Raj perform the role of a guardian of markets? After the governance of India was taken over from the East India Company by the British Crown, there emerged three centres of government, the India Office in London under a Secretary of State, the Viceroy or the Governor-General seated in Calcutta (Delhi after 1911), working in

13 This loose definition of the Raj is consistent with an emerging theme in the history of the world economy since 1800. A series of works in imperial history in recent years has traced the prehistory of modern globalisation in British imperialism and the spread of settler societies. For a review essay, see Cain (2012). 
consultation with a Council, and the provincial governments headed by Governors. In order to maintain market integration between Britain, India and the colonies, the rulers of India used three principal means, control on the monetary system which was exercised by London, commercial laws which were overseen by the Viceroy's Council in India and the army. Public goods such as roads, schools and hospitals were looked after by the provinces. Calcutta and London needed to work in concert to run the fiscal operation and the army, which were managed in India.

A significant function of the state - managing the monetary system was performed in London. The India Office raised money from the City of London, balanced international obligations by selling bills and invested the reserves in the City. The decision to conduct these financial operations in London was justified by the argument that London could supply funds in larger volume more cheaply because the transaction cost of financial operations was moderate there. The facility to borrow abroad was crucial for the Raj because its main source of income, land taxes, was unstable and insufficient for investment plans. The relationship between the City's finance capital and the Indian Office was so close that debt instruments took a bewildering variety of forms each serving a specific need, including government stock, sterling bill, war loan and loans of railway companies (Sunderland 2013). Occasional crises aside, until World War I, these deals facilitated Indian trade, borrowing abroad and the balance of payments.

One of the goals of the monetary system was to stabilise the exchange rate. An appreciation of the Indian currency, the Rupee, hurt Indian trade, and depreciation made it difficult for the budget to meet its foreign obligations (known as Home Charges). The balancing act was difficult but manageable as long as the British economy was growing. The only crisis then came from fluctuations in the value of silver. The Indian rupee being a silver coin, its market value was sensitive to the gold-silver exchange ratio. A depreciation of silver should devalue the rupee, and rise in silver price revalue the rupee. These processes were not automatic, and in the case of a delayed adjustment, the exchange rate management hurt either business or the budget.

If the monetary system was closely managed, the record of the Empire in creating public goods was marked by a lack of sustained commitment. In part the limited engagement had owed to the poverty of the state. The Raj ran a small government (Figure 1). In the 1920s, nominal tax collection per capita was $<2$ per cent of tax per head in Britain (adjusted by purchasing power, 6 per cent). British India was poor also in relation to most of Britain's tropical colonies and other Asian countries in the interwar period. Between 1920 and 1930, the government of the Federated Malay States spent on average more than ten times the money spent in British India per head, that of Ceylon spent more than three times, those of the Philippines and the Dutch East Indies more than double, and those of Siam and French 
FIGURE 1

COMPONENTS OF GDP IN 1900 AND 1946 (MILLION RUPEES, 1938-9 PRICES)

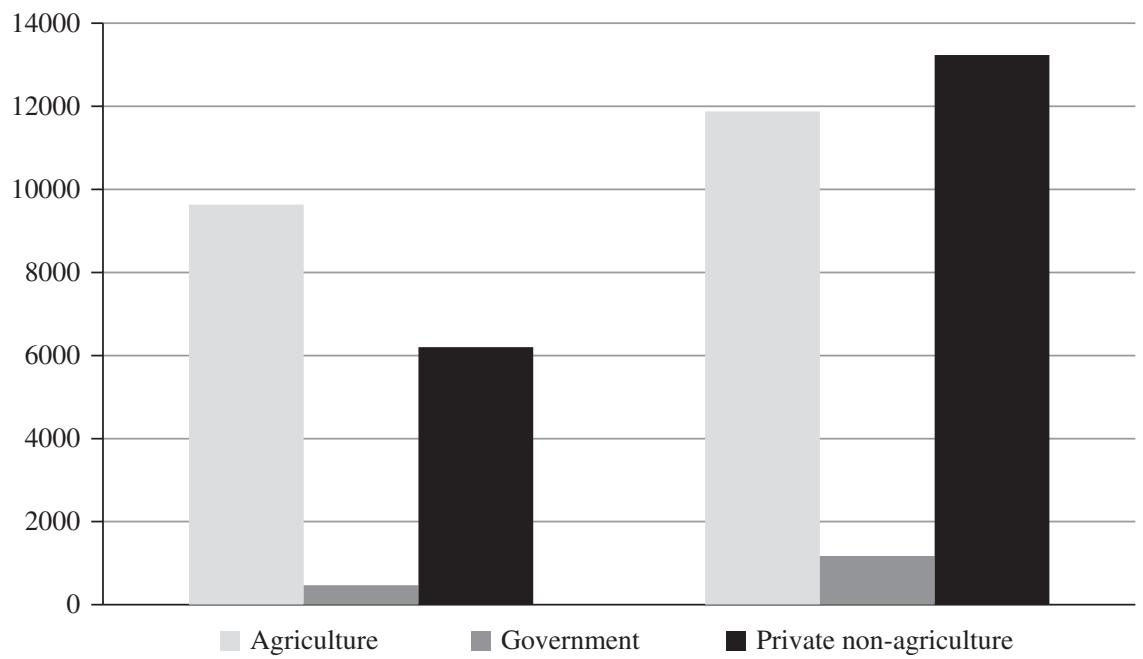

Source: As Table 1.

Indochina 40-50 per cent more (Roy 1996). The Raj was a small government also in relation to its own national income. Government revenue as a proportion of national income was 2 per cent in 1871 and marginally higher at 3-5 in 1920-1930. It was 19 in Britain and 29 in Japan in the interwar years.

An analysis of the revenue budget would explain the size of the state. More than half of the revenue came from land tax in the $19^{\text {th }}$ century. The land tax was a tax on area of agricultural land privately owned. The tax per area was low because agricultural yield per area was low in India. And it was stagnant because yield was stagnant. As land tax per area remained roughly constant over time, population growth made tax per head fall. Compensating forms of taxation such as customs duties and income tax were not tried until World War I due to the free trade policy or resistance by wealthy Indians.

A government by a handful of foreigners in a huge country that had shown its capacity for hostility during the Great Indian Mutiny (1857) needed to mind survival first. The Raj did this, and the Company did it before 1857 , by spending a significant proportion of the revenue on military heads. Until World War I, the British army was more or less the same thing as the Indian army. It was funded out of the Indian revenues. Whether it could be used for British campaigns or not was a point of negotiation between Britain and India until 1923, when Britain agreed to pay a fee for the services of the 
Indian army. In the eyes of the rulers of India, the army brought peace in a region that had seen repeated conflicts in the $18^{\text {th }}$ century. In both the World Wars, the Indian army was engaged. Its value was also seen in terms of maintaining peace in the wide expanse of the world where the Empire had created a vast market place.

After monetary system and the military, a third area of state activism was law. Intervention in this sphere cost the Empire a lot less money, and was politically less controversial too, partly because colonial law minded both indigenous law and political constraints. Legislative activity accelerated after the Mutiny, and slowed after 1900. The average number of «supreme government acts» passed every year was 0.6 in 1835-1850, 1.8 in 1880-1900 and fell rapidly thereafter. The most frequently used among the new laws were those related to procedure in general, and business procedure in particular. The Code of Civil Procedure 1908, the Indian Contract Act 1872, the Evidence Act 1872, Limitation Act 1908, Stamp Act 1899 and Registration Act 1877 accounted for 70 per cent of all High Court suits settled in 19001910. The pattern of legal reference in these years suggests that the legislative process responded to problems of business transaction. By the same logic, legislative drive weakened later because international business was in retreat after World War I (Roy and Swamy 2016).

Such was the political economy of the Raj. Can we measure the economic effect of the political economy?

\section{ECONOMIC CHANGE: GENERAL PATTERNS}

Per capita income rose exceedingly slowly in the colonial period, possibly just above 1 per cent per year in the late $19^{\text {th }}$ century (Heston 1983), and near-zero in the early $20^{\text {th }}$ century (Sivasubramonian 2004). But average income is a misleading statistics for colonial India. When we decompose the average income, we see that there was consistently poor growth of agriculture, and consistently robust growth in income from trade, construction and manufacturing. Rather than the slow growth of average income, it is the divergence between agriculture and non-agriculture that needs to be explained with reference to the political economy of the Empire.

Colonial India was predominantly an agricultural economy (Figure 1). The agricultural seasons were short everywhere because of the region's tropical monsoon climate. The monsoon rains ensured one rain-fed crop in most parts of the region. But extension of the cultivation season, raising water-intensive crops like sugarcane and raising the intensity of cultivation, depended on the availability of irrigation water from rivers, lakes and wells. In the best of times the mechanisms to extract and recycle groundwater were exceedingly expensive, well beyond the means of most peasants. This is so because in two-thirds of the South Asian land mass, underground water 
TABLE 1

GROWTH RATES OF REAL NATIONAL INCOME

\begin{tabular}{|l|c|c|c|}
\hline & National income & Population & Per capita income \\
\hline $1860-1885$ & 1.8 & 0.5 & 1.2 \\
\hline $1885-1900$ & 1.0 & 0.6 & 0.5 \\
\hline $1900-1914$ & 1.4 & 0.4 & 1.0 \\
\hline $1914-1947$ & 1.4 & 1.1 & 0.1 \\
\hline
\end{tabular}

Sources: Heston (1983) and Sivasubramonian (2000).

occurs in hard-rock aquifers that are costly to drill and difficult to map. The risk that a well, created with relatively large investment, would dry up or fail to supply water was relatively high. In the Gangetic plains, by contrast, groundwater occurs in alluvial aquifers, which the peasants did exploit more fully. Borewell technology began to develop in the interwar period, and was not affordable until the 1970s. The British engineers built, and in some cases revived, a few large river-based canals. These canals came up in areas where perennial rivers existed and were large enough in size. The most important such areas were Punjab, where the Himalayan snowmelt rivers were used effectively, the Godavari and Krishna deltas in the south-eastern coast and the Ganges plains in north India. If the agricultural village was located in one of the few canal-irrigated zones the peasants benefitted by producing more crops for the export market. But if it was located in a rain-fed and arid zone, it was more than likely that the land would produce too little even for a comfortable subsistence.

Between 1900 and 1946, GDP increased by 60 per cent. With population growth beginning to accelerate in the first half of the $20^{\text {th }}$ century per head income rose by only 10 per cent (Figure 1 and Table 1). The average standard of living changed so little because GDP in agriculture, which employed over 70 per cent of the workforce, grew by 15 per cent in these years (Figure 1). Given the size of agriculture, stagnation in this sector depressed wages all round and made poverty too common. Land productivity was low by international standard, stagnant and sometimes falling between 1890 and 1947 (Blyn 1962). Marxist historians attributed the stagnation to property right reforms and colonial markets resulting in progressive indebtedness and impoverishment of the peasants ${ }^{14}$. The historical record on the peasants, however, is too mixed and differentiated for any generalisation to be sustained ${ }^{15}$. The evidence that when trade and transportation costs were relatively low and canal water was

\footnotetext{
14 See editorial introduction in Bose (ed.) (1994).

15 See Roy (2011) for survey of these debates and essential references.
} 
available, the peasants perceived, responded to and gained from profit opportunities, and that debts were in such cases often a sign of prosperity and not distress is robust enough. Further, if colonial intervention were to explain low and stagnant agricultural yield, we need to show that yields were higher and upwardly rising before colonialism (or in areas not directly ruled). There is no compelling evidence to show this (Roy 2013).

An alternative interpretation is that the tropical climate and attendant water scarcity depressed production possibility, and thus limited the prospect of agricultural commercialisation to only a few regions. In the past, low land yield left states including the British Indian state in possession of limited fiscal resources, and exposed the population to consumption and famine risk. The syndrome of low yield persisted until the 1970s, when the Green Revolution broke the pattern in some regions of South Asia. Outside these regions, and relative to world standards, the low-yield condition still persists despite vast changes in technology.

Compared with the bleak agricultural situation, trade offers a dynamic scenario. Between 1900 and 1946, private enterprise outside agriculture doubled in size (Figure 1). Agriculture was not the main source of sustenance of capitalism; the dynamic impulse came also from the Indian Ocean and the world economy. Private enterprise outside agriculture was the area most touched by free trade, foreign investment and skilled labour migration, sponsored by the Empire. From long before the British Empire began, the region had traded actively. Its geographical diversity, wealthy cities, strategic position between Arabian Sea and Bay of Bengal trading zones, and fertile deltas ensured that land trade and caravan trade in textiles, grain or cotton were well developed. Bankers who financed long-distance trade could be found in the major towns located on rivers and caravan routes. These enterprises were stimulated during the 200 odd years when the powerful Mughal Empire ruled much of southern Asia (c. 1526-1720). In the 1600s, European trading companies were attracted to India because it could offer both tradable commodities like spices and textiles and well-developed institutional infrastructure geared to trade.

As the Mughal Empire collapsed from the 1720s, a number of merchants and bankers migrated to the capitals of the rising regional states such as Hyderabad, Lucknow, Pune as well as the three port cities, Bombay, Calcutta and Madras, which had been established by the British East India Company in the $1600 \mathrm{~s}$. In the $19^{\text {th }}$ century, more of the Indian capitalist migration was directed to these ports. The Company's own reach in Asia and Europe increased access of the Indian merchants of these cities to first Chinese and then British markets, and the access of British investors to projects in India, including railway construction and banking and insurance businesses. The bankers of Bombay and Calcutta could rediscount hundis (the indigenous trade bill) and invest in shares readily because big corporate banks of the cities, and the British Indian courts, recognised these instruments. 
Soon after the British Industrial Revolution became a global force around the early-to-mid-19 $9^{\text {th }}$ century - the Empire became the main destination of Indian export. Relatively speaking, there was a diversion of Indian trade from China to Britain and its colonies, dominions and parts of the world where British commercial access was established. Likewise, Britain was the major source of India's imports until World War I. Whereas in the $18^{\text {th }}$ century, Indian exports consisted of artisanal manufactures like fine textiles; in the $19^{\text {th }}$, exports consisted of primary products such as grains, seeds, raw cotton, hides and skins, oilseeds and raw jute, and imports consisted of manufactures, mainly Manchester yarn and cloth. The opening of the Suez Canal in 1869 much reduced the cost of carrying bulk goods from and to India.

The estimated volume of foreign trade to and from India more than doubled in 1865-1914. The volume of trade through the three British Indian ports increased from 1.6 million tonnes in 1863 to 8.6 million tonnes in 1913 (the figure includes coastal trade). The figure dropped thereafter to recover to 10 million in 1937. The estimated ratio of foreign trade in national income increased from 8-10 to 20 per cent in 1865-1914. Because foreign trade involved agricultural goods, overseas trade and overland trade became interdependent in the $19^{\text {th }}$ century. In the coastal trading world, a string of British and European firms purchased agricultural commodities for export from merchants specialised in overland trade. Exports of agricultural goods began to rise, and overland trade in agricultural commodities was further stimulated by railway expansion. Shipping tonnage data suggest that the acceleration in maritime trade had started from the 1850s, when the first major railway lines were opened. The railways that came up in the Indo-Gangetic plains drew cargo away from boats and carts, but the lines that appeared in peninsular India, which had earlier relied on the expensive and slow bullock caravans for the transport of bulk goods, revolutionised transportation links between the land-locked interior and the seaboard. The bankers and traders who remained inland took part in commodity trade on a larger scale than before. The merchants were financed not by the small number of corporate banks, but by indigenous bankers and moneylenders. By 1920, the biggest market for rediscounting of indigenous trade bills, the hundi, was located not in the interior, but in Bombay and Calcutta.

In the second-half of the $19^{\text {th }}$ century, some of these entrepreneurs were setting up large-scale mechanised factories. Manufacturing industry was embedded in the trading world of Bombay, Calcutta and Madras. Among those Indians who dominated industrial investment around 1900, one segment had always been based in the coasts, like the Parsis, and another segment, like the Gujaratis, had moved from overland trade or banking towards overseas trade from the late 1700s. After the Crown took over Indian administration from the Company (1858), foreign investors joined these indigenous business communities. The first modern factories were 
established by these groups making use of their knowledge and control of commodity trade, especially trade in cotton, and overseas markets. In turn, profits accumulated in business went into public and community goods. At the time of Indian independence, these cities were homes to some of the best schools, colleges, hospitals, universities, banks, insurance companies and learned societies available outside the Western world. A big part of that infrastructure had been created by the Indian capitalists.

By 1914, the fourth largest cotton textile mill industry in the world financed and managed by Indians had come up in Bombay. A third of the cotton spindles in use outside Western Europe and the United States was installed in India, and over half of the spindles installed in the tropics was in India. A jute textile mill industry, which supplied packaging material to the commodity traders of the whole world, had emerged in Calcutta under European management, with considerable Indian shareholding. Between 1850 and 1940, employment in factories increased from $<100,000$ to 2 million, at an average annual rate of 4 per cent (Roy 2011). Real GDP at factor cost originating in factories rose at the rate of 4-5 per cent per year between 1900 and 1947, and employment at 4 per cent (Sivasubramonian 2000, pp. 201-203, 287-288, 293-294). These rates were comparable with those of the other emerging economies of the time, Japan and imperial Russia, and considerably more impressive than the patchy and uneven industrialisation in the rest of the contemporary tropical world.

Much modern enterprise such as factories, corporate banking, insurance, technical schools, hospitals, universities and public services needed to import services from Europe. India had goods to sell. It did not have an adequate supply of skills and technology. In order to set up factories, Indian businesses imported not only machines, but also the engineers and the foremen to operate these. Likewise, expatriate doctors, scientists, university teachers, lawyers and military personnel were routinely hired by firms and organisations, even when these were owned by Indian firms. In this way, there emerged a distinctive feature of the Indian balance of payments. From a book-keeping angle, India maintained a surplus on the trade account, and a deficit on the services account. One of the larger components in the payment was the Home Charges, a payment made by the government on account of debt service, pensions, railway subsidy and other heads. Private outflows, such as repatriated profits or remittances by managers and employees of foreign firms, were probably larger (Table 2).

It should now be clear from the foregoing discussion that any assessment of the British Empire in India must be able to explain its agency in producing two contradictory facts. First, trade and manufacturing grew relatively rapidly. Second, agricultural productivity was low and stagnant, imparting a depressive effect on wages of manual workers and per capita income. How can we explain these facts together, and with reference to state policy? 
TABLE 2

COMPONENTS OF THE BALANCE Of PAYMENTS (1898)

\begin{tabular}{|l|c|c|}
\hline & Million rupees & \% of GDP \\
\hline Net export & 147 & 1.14 \\
\hline Home charges & -220 & -1.71 \\
\hline Net government debt & 220 & 1.71 \\
\hline Invisibles & -322 & -2.50 \\
\hline Foreign investment & 40 & 0.31 \\
\hline
\end{tabular}

Note: The Indian rupee stood at 17:1 with respect to pound sterling in 1898 .

Sources: Banerji (1995) and Sivasubramonian (2000).

\section{HOW DID THE STATE SHAPE ECONOMIC CHANGE?}

The Empire helped capitalist growth indirectly by keeping borders open, passing new laws of contract and negotiable instruments, and making sure that the military and naval power protected sea routes and aided South Asians going to China, Southeast Asia, Central Asia and Africa for trade. And it made India an attractive destination for British capital. Directly, the Empire neither helped nor obstructed the growth of trade and industry. After the large defence spending was taken out of the budget, the state had little left to spend on welfare or infrastructure. The Raj did not directly help Indian industrialisation, as the openly pro-Lancashire tariff policy until the 1920s showed. But nor did it try to stop it.

The most striking legacy of the open economy was industrialisation. Interestingly, industrial capitalism emerged in a region where textbook prerequisites for industrial capitalism to emerge had been missing in 1850 . Factor prices, for example, were unfavourable; interest rates were twoto-three times higher in India than in the financial centres of Europe. An activist state, which Alexander Gerschenkron and his followers treat as an axiom for catching up industrialisation, was absent. The Empire that ruled India was as far away from the «big push» of early development economics or the "embedded autonomy», "developmental state» and "governed market» that account for the industrialisation of East Asia as we can imagine ${ }^{16}$. Post-war development theory and socialist models set store on a high rate of saving. The saving rate in India was around 5 per cent of GDP in 1920. A lot of private saving was locked up in gold and silver jewellery. Historians of early modern Britain stress the contribution of a prior agricultural revolution to British industrialisation (Wrigley 2006). Indian agriculture was

16 On these concepts, see Chang (1999) and Johnson (1999). 
characterised by some of the lowest yields on record, and as far as we can reliably measure, experienced no secular trend in yield in the $18^{\text {th }}$ century.

If industrialisation was possible at all in spite of these obstacles, two factors were responsible above all, the availability of indigenous entrepreneurship in trade and finance, which brought down the cost of capital in transactions within the business community, and factor market integration. By facilitating movements of goods and people, the Empire reduced the cost of accessing knowhow needed by industry. As opposed to an earlier time when knowledge was carried abroad by migrant artisans, in the late $19^{\text {th }}$ century useful knowledge travelled in the shape of traded machines and manuals. Mass production of textile machines in England considerably reduced the transaction cost in the knowledge market. Bombay's merchants bought the machines, and hired from Manchester the foremen to work these. The language of business in the port cities was not English, but English was widely understood.

The very ease of buying machines seemingly made Indian mill-owners take little interest in technology. Persistence with British standards caused problems especially when Japanese cotton textile mills started competing with the Indian ones, from around 1890 (Kiyokawa 1983). Some of the technologies introduced in India had limited learning effect because they were managed by the state. Railways are an example (Headrick 1981). However, the positive externalities of foreign knowhow tend to be underestimated, possibly because they were so confined to the cities. In cotton textiles, between the first mill set up in 1854, and 1925, the percentage of Europeans among the supervisory staff decreased sharply. In another industry, iron and steel, imports from Britain hurt artisanal producers, but the easier availability of British knowhow encouraged import substitution by mid-sized firms using the reverberatory furnace and coking coal. An extraordinary development of endogenous skill building using the open market for skills was the firm of the Tatas. Initially, a textile producer, the founder of the house Jamsetji Tata, established an integrated steel factory in 1907. The vertical integration model that was planned, complete with coal washery, labour barracks, township building and mines, would have been unthinkable in 1850. It was feasible, if still challenging, in 1907 because of the railways connecting the mining sites, data available from geological surveys, an IndoEuropean advisory team, purchase contracts from the railways and heavy dependence on European (later American) supervisors in the shop floor. By the 1930s, the Tata steel plan successfully reduced its dependence on foreign experts and supervisors. In many skilled craft industries, the access to British knowhow brought new tools and cheaper manufactured raw materials within easier access to the producers (Roy 1999).

Openness, in other words, delivered growth impulses, among other ways by reducing transaction cost in knowhow. And yet, London's control over the Indian monetary system turned openness into a symbol of India's 
subordinate status in the political relationship, and made it highly disputatious. The first influential articulation of the sentiment against openness occurred in the writings of two publicists, Dadabhai Naoroji (1825-1917) and Romesh Dutt (1848-1909). Naoroji was a teacher-merchant-Parliamentarian and Dutt a civilian-cum-novelist. Both these writers had witnessed devastating famines sweep through western and southern India between 1876 and 1899 and felt compelled to develop a theoretical understanding of Indian poverty. Two ideas emerged with special force from their writings. Dutt believed that the famines were a result of high taxation in the countryside. In his lifetime, agricultural commodity exports had grown in volume about three times, and canals and railways had transformed areas like Punjab from grasslands into wheat baskets. The British supporters of the Empire cited Punjab as a showpiece. Dutt suggested instead that by and large Indian peasants did not gain from foreign trade. In fact, by selling too much food abroad they reduced chances of survival during famines. Trade also destroyed the handicrafts, and the unemployed artisan crowded agriculture, putting more pressure on land (Chandra 1966; Bagchi 1976). Naoroji was known for a different idea. The main thrust of his analysis was that India paid too high a price for the services it imported from Britain, which payment he called «drain». This was an indirect criticism of trade because the services were paid for with trade. Both writers, in effect, said that the open economy had failed because it worked to serve British economic interests at the expense of Indian economic growth and welfare.

The nationalist narrative has not stood up to test all that well. The narrative had two main points of emphasis, drain and deindustrialisation. The drain theory of Indian poverty calculated the export surplus and factor payments, but attempts to assess the value of the services purchased with factor payments proved to be a difficult task ${ }^{17}$. Like any payment made by governments anywhere in the world, there was a lack of accountability in the remittances that formed parts of the Home Charges. But these were also a payment for skills, and it is impossible to imagine an economy short of skills industrialising without having to buy skills from abroad.

Consider deindustrialisation next. Decline of artisan industry was a fact, of course, but India was no exception on that point. What was exceptional about India was that the region experienced growth of factory industry from the mid- $19^{\text {th }}$ century, and that millions of surviving artisans experienced a rise rather than a fall in their wages and earnings (Sivasubramonian 2000). The nationalism that shaped Indian economic policy for 40 years after 1947 assumed that the failure of colonialism was a failure to industrialise India because domestic capital was exposed to foreign competition. This was the wrong lesson to draw from history. The non-agricultural economy was in fact

17 For example, see essays by K.N. Chaudhuri, John McLean, Sundanda Sen, and the editorial introduction in Balachandran (ed.) (2005). 
a source of capitalist expansion. Openness had delivered commercialisation and industrialisation. The problem was agricultural productivity. Neither drain nor deindustrialisation could explain why agricultural productivity was so low for so long.

On one crucial point, however, the nationalists made a compelling argument. The $19^{\text {th }}$ century famines were reminders of how badly the government performed as a guardian of welfare. Whatever the justification for the size of the army, adding defence to civil administration and debt service, there was little left in the small budget for productive investment. Public investment (infrastructure, education and healthcare) took up 21 per cent of government revenue before the War. Irrigation canals, roads, railways and telegraphs received government investment. But the proportion was low in the best of times (4-6 per cent of GDP around 1900), and the expenditures were cut in the interwar period as the government finances turned adverse. Subsequently, new investment went mainly into repairs of these assets. The biggest casualty of the public goods paralysis was investment in agriculture.

Notwithstanding the famines, it cannot be said that until World War I, public opinion was ready to support a freedom movement. That condition changed in the interwar period, when a powerful combination of forces began to shape views about the existing state, and in turn, views about how the nation state of the future should act to develop the country. Why did that turning point occur?

\section{WHY THE EMPIRE FELL}

Neither drain nor deindustrialisation worried the Indian capitalists too much in the $19^{\text {th }}$ and the early $20^{\text {th }}$ century. And yet, by the $1930 \mathrm{~s}$, a number of prominent industrialists had started financing the freedom movement. Increasingly, the Indian capitalists worried that the lack of monetary autonomy would hurt private enterprise while the state, which was going steadily bankrupt, tried harder to balance its budgets by manipulating currency. As some of the payments abroad were made by the government, the government had an interest in avoiding depreciation, as we have seen. Facing a difficult fiscal situation in the 1920s, the colonial government had done just that, at the expense of business interests.

The critical weakness of the Raj was the manner in which monetary policy and military policy were decided in London. By making both of these fields non-negotiable prerogatives of London, during much of its career the Raj appeared to the educated Indians as a «military despotism». In political culture, it reflected that aggressive elitism. For 8 months in a year the government sat in a remote hill station insulated from the heat and squalor of the plains. Its proceedings were ritualistic. The Viceroy was technically advised by a Council, but the deliberations within the Council did not allow for open 
discussion. The government left no room for internal debate and introspection. There were no Indians in the secretarial staff around the Viceroy. A reform measure in 1909 had introduced a few elected members in the Council, but that did nothing to change the ritualistic mode of its functioning.

The fiscal operation reflected the despotism. Because of the priority that defence enjoyed, effective decentralisation of the public finances remained a slow and limited process. Provinces - in charge of healthcare and education - were the least well-funded among the three arms of the government, and they complained bitterly about it. The introduction of elected legislatures in 1919 and 1935 modified this setup, but did not replace it.

By 1900, the government of India had grown immune to criticism. It did not help that the major platforms for criticism were located outside the government. The Indian National Congress was established in 1885. At that time, there was lively associational activity in the port towns. The Congress was formed partly as an initiative to coordinate some of that activity. Around 1900, the Congress began to make serious demands for representation and self-government. These demands took on an international colour by borrowing the words Home Rule from the Home Rule party in Ireland. The demands were met with repression until the end of World War I. When it became evident that Indian contribution to the War had been vital to Britain's victory, a conciliatory stance was adopted leading to legislatures in the centre and the provinces. These were significant reforms, but only when seen against the extraordinarily rigid political setup that had functioned until then. Few Indian politicians were happy with these moves. In any case, events overtook these reforms quickly.

Until 1920, nationalism in India was shaped by the views of the Empire's critics in the port cities. They consisted of the educated Indians, some of whom had grievances against the racially prejudiced way recruitment and promotion were done in the higher levels of the government. Public intellectuals gave some substance to that disjointed critique, but in themselves, these voices did not have much political effect. When the Congress got its act together in the 1920s, bigger issues like poverty, famine and welfare came to the forefront. Agriculture became a rallying point in the nationalist movement in the 1930s. In that decade, the nationalist leader M.K. Gandhi, who had recently returned from a legal career in South Africa, successfully turned an elitist political movement into a mass movement by going to the countryside. The mounting agricultural crisis made the move timely.

The Congress was divided between a socialist group and a pro-business group. Despite many differences between them, they shared an agreement on the need to build a large state and an economy protected from foreign trade and foreign capital. Why a generation of capitalists who had made their money in the open economy would turn their back upon openness is something of a puzzle. Partly, the reaction owed to the collapse of the world 
economy late in the interwar period, which exposed the structural weaknesses of the imperial state. After the Great Depression of 1929 more or less ended the globalisation process, Indian business lost interest in the world economy and some of them started to finance the independence movement. Among those business interests who joined the independence movement, there were several who hoped that their future would be better secured by a protected economy than an open economy ${ }^{18}$.

After World War I, the British economy had lost international lead, the Sterling was not the world's favourite currency, and the British imperial administration wanted the colonies to do more to compensate for these losses. At the same time, India's contribution to the War strengthened a lobby that wanted more autonomy for India. Through the 1920s and the 1930s, these two lobbies disagreed over different aspects of economic management. The share of Britain in Indian imports fell. Asian trade was stimulated by the emergence of modern industry in Japan. The Asian surge worried the rulers of India, and was the impetus to the Imperial Preference (1932), which tried to create a customs union among the British colonies. It is not surprising that the move was resented by many Indian firms as well as the lobby demanding more autonomy for India. As the Sterling became unstable the external accounts faced a predicament. Indian businesses contended that the India Office was shielding the budget at the cost of business by maintaining an overvalued exchange and by deflating the economy (Tomlinson 1979; Balachandran 1996). A long-standing claim by the Indian nationalists that London's financial operations made India serve Britain's economic interests acquired wider acceptance. Britain did grant India monetary autonomy in 1935 in the shape of the Reserve Bank of India, but the move came too late.

In the 1940s, when independence was imminent, a blueprint of development drawn up by a group of wealthy capitalists and known as «the Bombay Plan» declared that the future of India should be a closed economy and a state-dominated economy (Kudaisiya 2014). Where did that idea come from? It did not come from a reading of history. The Bombay Plan, like a number of other plans designed in the decade before 1947, was shallow in its reading of history. It bypassed agriculture, rejected trade, forgot to mention foreign firms and deferred without good reason to the socialist lobby. The most famous member of the socialist set was the first Prime Minister Jawaharlal Nehru. By paying respects to socialist politicians, the authors of the Bombay Plan possibly hoped to gain unconditional access to Indian markets in return ${ }^{19}$.

18 On business-politics relationship in these times, see Markovits (2002).

19 It needs to be said that the capitalists who thus joined the campaign for strong protection from trade and foreign investment were a minority. The vast majority consisted of trading firms, and the foreign firms, who were more or less unrepresented in the politically most powerful and organised groups of business persons in this time of transition. 


\section{AFTER THE EMPIRE: ECONOMIC NATIONALISM}

In 1947, the South Asian mainland was partitioned into two countries, India and Pakistan, and in 1971, a further division took place with the birth of Bangladesh. Despite these far from peaceful changes in the map, the transition to a national economy in each case, especially in India, occurred with relatively little friction, owing to substantial continuity in institutions, an indigenisation of the bureaucracy effected in the final years of the Raj and the legislative reforms of 1919 and 1935.

After independence, the Indian Union chose to carry out importsubstituting and state-directed industrialisation. The strategy, which was a departure from the cosmopolitan capitalism of the Empire era, received intellectual support from the export pessimism ruling the world in the 1950s, and socialist lobbies within the Congress that advocated central planning. The lesson learnt from history was that India needed to insulate its economy from trade and investment and build a strong state and closely regulated markets. Development policy was inspired by this reading of the past. GDP growth rate was raised sharply by a substantial increase in government investment. Protection was raised to very high levels and reinforced with non-tariff barriers. Commodity export was discouraged. The fear of a recurrence of famines and shortages led to state control over grain trade. Independent India, thus, set out to replace the Raj's legacy of a small state, free market and open economy with a large state, public control of markets and assets, and an insular economy. This was done with such commitment that 40 years after Independence, trade and foreign investment had been reduced to insignificance, and the size of the government relative to GDP grown seven times in 1931-1981.

The strategy hurt vast numbers of capitalists who had depended on the open economy. Excessive regulation compromised the quality of institutions ${ }^{20}$. There was attrition of enterprise. For example, between 1950 and 1970, except a few multinationals selling goods to Indians, the British firms that were engaged in commodity trade and industry were squeezed out of India. The ones in Calcutta lived on the export of jute and tea, procured capital and technology from abroad, and recruited top management internationally. The nationalist state sharply raised tariffs and capital controls, which made taking any of these steps more difficult than before. The investment policy raised investment cost in businesses that had long relied on imported capital, knowhow and expertise. Exports suffered in jute and

20 Three comparative indices directly or indirectly focus on institutional quality, and all rank India low among a basket of countries. These are the Global Competitiveness Index, the Global Innovation Index and the World Bank's Ease of Doing Business Index. The last mentioned ranks India very low on the ease of contract enforcement. http://www.weforum.org/reports/globalcompetitiveness-report-2014-2015, https:/www.globalinnovationindex.org/content.aspx?page=GIIHome, http://www.doingbusiness.org/reports (all three accessed 20 July 2015). 
tea. The trade-GDP ratio fell to a third of what it was (1970 compared with 1920). Commodity trade was partially nationalised and commodity export in the private sector was practically banned. The global firms operating in India were squeezed from two ends; they lost their foothold in export trade whereas they never had a foothold in inland trade. A series of hostile takeovers by opportunistic Indian trading families sealed the fate of the global firms. The retreat of Western interest in India led to a dysfunctional dependence of Indian trade on the communist bloc.

On the other hand, the free nation was readier to raise and spend large sums of money on development. One of the major successes of public spending was the absorption of new high-yielding agricultural technology in the 1970s, which not only raised output and productivity above historical levels, but also raised rural wages. The strategy led to an expenditure commitment that was heavy and sustained. Conventional public goods such as schools, hospitals and urban infrastructure were often neglected because subsidies to agriculture and non-performing state-owned industry consumed a great quantity of public money. Still, it required a national state to muster both the resolve and the resources to undertake an ambitious development plan.

In conclusion, let me return to the comparative history questions the paper began with.

\section{CONCLUSION}

A summing up of the narrative history is in order. The British Empire of the $19^{\text {th }}$ century inherited two things from the East India Company, a commitment to maintain an open economy, and a large military force. In the $19^{\text {th }}$ century, these two things became compatible assets of great value to Britain. The open economy sustained by British military might was an asset for many Indian capitalists too. National income statistics show that private non-agricultural enterprise experienced significant growth in the early $20^{\text {th }}$ century. But the means used to maintain openness - London's control of monetary and military policy, and a neglect of developmental expenditure became controversial and eventually brought the Empire down by making it unattractive to Indian capitalists.

Using this narrative, the paper offers two sets of lessons, one for comparative history and another for the study of post-colonial development in India. Where did real power lie in this regime, with the dominant core (equivalently, capitalists located in the core), or among settlers in the periphery? Settlement, in fact, was a more or less irrelevant fact in this case. The core was the clear source of power. London did make key economic decisions for India, and tried to monopolise its control over these decisions. What did power achieve? The core ruled not in order to devise and maintain extractive ethnically biased institutions, and eventually replace these with 
benign and efficient European ones. That idea popularised in the settler economy literature does not work for India. The core ruled in order to sustain economic integration. The core ruled not by means of unequal laws, but by taking the reins of the monetary system, and indirectly, the fiscal system. It wielded these instruments in order to stabilise trade and currency, reduce risks of exchange and maintain the Indian state's payments to Britain. In short, it ruled to sustain openness, as the term would be understood in the context of the pre-war British world.

This proposition works as a link between colonial and post-colonial India. If British colonial policy in India was framed with reference to a global economic order, post-colonial policy in India was framed with reference to economic nationalism, namely, the idea that a strong nation needed a strong economy. The strong national economy should be led by the state, and if need be, insulated from world competition. In respect of macroeconomic environment, the key differences were openness and the size of the state. The openness of the colonial era had led to the emergence of a robust cosmopolitan capitalism centred in the port cities. But maintaining openness carried significant costs. The costs came in the forms of a despotic political culture that prioritised military expenses above all other forms of spending, and the failure to address the key challenge of development, transforming rural livelihoods. Driven by economic nationalism, the post-colonial state nearly destroyed the cosmopolitan heritage of the colonial times, and devitalised trade. But it raised much larger funds for investment, without which the agricultural revolution of the late $20^{\text {th }}$ century would be unimaginable.

\section{REFERENCES}

Acemoglu, D.; Johnson, S., and Robinson, J.A. (2001): "The Colonial Origins of Comparative Development: An Empirical Investigation». American Economic Review 91 (5), pp. 1369-1401.

Ambirajan, S. (1978): Classical Political Economy and British Policy in India. Cambridge: Cambridge University Press.

BAGCHI, A. K. (1972): "Some International Foundations of Capitalist Growth and Underdevelopment». Economic and Political Weekly 7 (31/33), pp. 1559-1570.

BAGCHI, A. K. (1976): «Deindustrialization in India in the Nineteenth Century: Some Theoretical Implications». Journal of Development Studies 12 (3), pp. 135-164.

Balachandran, G. (1996): John Bullion's Empire: Britain's Gold Problem and India Between the Wars. Richmond, VA: Curzon Press.

Balachandran, G. (ed.) (2005): India and the World Economy, 1850-1950. New Delhi: Oxford University Press.

BANERJI, A. (1995): Aspects of Indo-British Economic Relations 1858-1898. New Delhi: Sage Publications.

BARber, W. J. (1975): British Economic Thought and India, 1600-1858: A Study of Development Economics. New York, NY and Oxford: Clarendon Press.

Berg, M. (1979): «Review of Classical Political Economy and British Policy in India by S. Ambirajan». Journal of Economic Literature 17 (2), pp. 536-538. 
Blyn, G. (1966): Agricultural Trends in India, 1891-1947: Output, Availability, and Productivity. Philadelphia, PA: University of Pennsylvania Press.

Bose, S. (ed.) (1994): Credit, Markets and the Agrarian Economy. Delhi: Oxford University Press.

BREwer, A. (1990): Marxist Theories of Imperialism. London and New York, NY: Routledge.

CAIN, P. J. (2012): «The Economics and Ethics of British Imperialism». The Historical Journal 55 (1), pp. 249-261.

Chandra, B. (1966): The Rise and Growth of Economic Nationalism in India. Delhi: People's Publishing House.

Chang, H.-J. (1999): "The Economic Theory of the Developmental State», in M. Woo-Cummings (ed.), The Developmental State. Ithaca, NY: Cornell University Press, pp. 182-199.

DARWIN, J. (2013): Unfinished Empire: The Global Expansion of Britain. London: Bloomsbury Press.

Elson, R. E. (1994): Village Java Under the Cultivation System, 1830-1870. Sydney: Allen and Unwin.

Engerman, S., and SoKoloff, K. L. (2013): «Five Hundred Years of European Colonization: Inequality and Paths of Development», in C. Lloyd, J. Metzer, and R. Sutch (eds.), Settler Economies in World History. Leiden: Brill, pp. 23-53.

HАвIв, I. (1985): «Studying a Colonial Economy - Without Perceiving Colonialism». Modern Asian Studies 19 (3), pp. 355-381.

HASAN, F. (2004): State and Locality in Mughal India: Power Relations in Western India, c. 1572-1730. Cambridge: Cambridge University Press.

Headrick, D. (1981): The Tools of Empire. New York, NY and Oxford: Oxford University Press.

Heston, A. (1983): «National Income», in D. Kumar (ed.), The Cambridge Economic History of India, Vol. 2 (1757-1970). Cambridge: Cambridge University Press, pp. 376-462.

Irigoin, A., and Grafe, R. (2012): «A Stakeholder Empire: The Political Economy of Spanish Imperial Rule in America». Economic History Review 65 (2), pp. 609-651.

Johnson, C. (1999): "The Developmental State: Odyssey of a Concept», in M. Woo-Cummings (ed.), The Developmental State. Ithaca, NY: Cornell University Press, pp. 32-60.

KiYokawa, Y. (1983): «Technical Adaptations and Managerial Resources in India: A Study of the Experience of the Cotton Textile Industry from a Comparative Viewpoint». Developing Economies 21 (2), pp. 97-133.

Kudaisiya, M. (2014): «The Promise of Partnership: Indian Business, the State, and the Bombay Plan of 1944». Business History Review 88 (1), pp. 97-131.

Lloyd, C.; Metzer, J., and Sutch, R. (2013): Settler Economies in World History. Leiden: Brill.

Lützelschwab, C. (2013): «Settler Colonialism in Africa», in C. Lloyd, J. Metzer, and R. Sutch (eds.), Settler Economies in World History. Leiden: Brill, pp. 141-168.

Markovits, C. (2002): Indian Business and Nationalist Politics 1931-39. The Indigenous Capitalist Class and the Rise of the Congress Party. Cambridge: Cambridge University Press.

OAK, M., and Swamy, A. V. (2012): «Myopia or Strategic Behavior? Indian Regimes and the East India Company in Late Eighteenth Century India». Explorations in Economic History 49 (3), pp. 352-366.

Osterhammell, J. (2014): The Transformation of the World: A Global History of the Nineteenth Century. Princeton, NJ and Oxford: Princeton University Press. 
Roy, T. (1996): «The Role of the State in Initiating Development: A Study of Interwar South and Southeast Asia». Indian Economic and Social History Review 33 (4), pp. 373-401.

Roy, T. (1999): Traditional Industry in the Economy of Colonial India. Cambridge: Cambridge University Press.

Roy, T. (2011): The Economic History of India 1857-1947. New Delhi: Oxford University Press.

Roy, T. (2012): India in the World Economy From Antiquity to the Present. Cambridge: Cambridge University Press.

Roy, T. (2013): An Economic History of Early Modern India. London: Routledge.

Roy, T., and Swamy, A. (2016): Law and the Economy in Colonial India. Chicago, IL: University of Chicago Press.

Semmel, B. (1970): The Rise of Free Trade Imperialism: Classical Political Economy: The Empire of Free Trade and Imperialism, 1750-1850. Cambridge: Cambridge University Press.

Sivasubramonian, S. (2000): National Income of India in the Twentieth Century. Delhi: Oxford University Press.

Sivasubramonian, S. (2004): The Sources of Economic Growth in India 1950-1 to 1999-2000. New Delhi: Oxford University Press.

StoKes, E. (1959): The English Utilitarians and India. Oxford: Oxford University Press.

Sunderland, D. (2013): Financing the Raj: The City of London and Colonial India, 1858-1940. Woodbridge: Boydell and Brewer.

Tomlinson, B. R. (1979): The Political Economy of the Raj, 1914-1947. Basingstoke: Macmillan.

Winch, D. (1965): Classical Political Economy and Colonies. London: The London School of Economics and Political Science.

Wrigley, E. A (2006): «The Transition to an Advanced Organic Economy». Economic History Review 59 (3), pp. 435-480. 